\title{
WORK OF THE MEDICAL RESEARCH COUNCIL
}

$\mathrm{T}$ HE recently issued report of the Medical Research Council for the year October 1, 1938-September 30, 1939*, covers a period of some difficulty owing to the disturbed condition of world politics, culminating in the outbreak of war. Nevertheless, a perusal of the report suggests that the progress of the research work pursued under the Council suffered little, if at all, from the state of war expectancy, except for some readjustments towards the close of the Council's year.

With regard to special war emergency services, the Council undertook the organization and supply of antitoxins, in particular tetanus and gasgangrene antitoxins, that might be required for war casualties, and sera and vaccines that might be needed in dealing with outbreaks of epidemic disease. The organization of an emergency laboratory service and of depots in the Home Counties for the collection, storage and supply of blood for transfusion purposes was also undertaken, and the Council frequently advised many Government departments which sought its assistance.

Nutrition in time of war, both as affecting the population as a whole under conditions of rationing, and the armed forces in respect of the great use of tinned foodstuffs in Service rations, were also the subject of investigation by the Council's staff. Government departments sought the assistance of the Council and of its Industrial Health Research Board on problems of industrial health, particularly in the production of war material, and special war problems are in course of investigation, such as shock occurring after serious wounds, sepsis complicating war wounds and physiological problems of aviation.

Passing to investigations on more general medical problems, a Committee on Preventive Medicine has studied methods of immunization against diseases such as diphtheria and whooping-cough with the view of evaluating their efficiency and determining the best technique, and has inquired into the problem of cross-infection in hospital wards. The causes of the high mortality rates due to broncho-pneumonia, to enteritis in children, and to respiratory diseases during winter have also been investigated.

The chemistry of brain reactions has been the subject of much research, and one of the facts established is the key position held by glucose as the main fuel of nerve tissue. It is also well established that substances normally present in the body perform specific functions in relation to

* Report of the Medical Research Council for the Year 1938-1939. (H.M. Stationery Office, 1940.) 38. net. the nervous system. In this connexion, Sir Charles Martin, Dr. Harriette Chick and their colleagues, working at Cambridge, have shown that when pigs are reared on a diet deficient in vitamin $\mathrm{B}_{6}$ they suffer from epileptic fits similar to those occurring in human epilepsy, and that when this vitamin is then added to the diet the fits cease. Prof. R. A. Peters and his colleagues at Oxford have likewise shown that when vitamin $B_{1}$ is deficient in the diet, both man and animals develop characteristic abnormalities of the nervous system. It was shown that, in the absence of this vitamin, the brain cells cannot make proper use of glucose as a food.

At the National Institute for Medical Research, Hampstead and Mill Hill, Dr. Stuart-Harris, Dr. Andrewes and Dr. Wilson Smith have conducted studies upon influenza. An epidemic occurred in the early part of 1939 which clinically resembled influenza, and attempts were made to isolate the influenza virus, which has a characteristic property in being transmissible to ferrets. Even with material from typical cases, all attempts to transmit a virus infection to ferrets failed, and only seven throat washings of patients, out of fifty-nine tested, yielded virus infective for ferrets. The outbreak, as a whole, appears to have been one in which the known influenza virus played a subordinate part, suggesting that other virus strains are capable of causing influenza-like attacks. Drs. Andrewes and Wilson Smith have also continued their experimental inquiry into the factors influencing the immunizing effect of the influenza vaccine.

The relation between human leprosy and rat leprosy was the subject of an interesting research by the late Sir Patrick Laidlaw. The rat disease, caused by an organism very similar to the human leprosy bacillus, is readily transmitted from rat to rat, but there is only one record of the successful transmission of human leprosy to the rat. Syrian hamsters, found by Adler of Jerusalem to be susceptible to infection with the human leprosy bacillus, were inoculated with human leprosy material, and one of the animals developed an infection with typical bacilli. With this material Sir Patrick Laidlaw found it easy to transmit infection not only to hamsters but also to white rats. A critical investigation by Sir Patrick suggested that the original material was derived from a case of human infection with the rat organism and not with the organism of human leprosy. The suggestion is made that human leprosy in the past may have arisen from the rat 
disease, the bacilli afterwards losing their infectivity for the rat with adaptation to the human tissues.

Work on biological standards, under the direction of Dr. Hartley, is also conducted at the National Institute, and various standards already established are maintained there. A British standard for a gas-gangrene antitoxin (histolyticus) has now been made available, and the British standard for diphtheria antitoxin has been placed on regular issue. Much work has also been done on the standardization of tuberculin, various other antitoxins, vitamins and insulin. The work of producing, standardizing and distributing bacterial suspensions and sera for diagnostic purposes has been continued at the Standards Laboratory, Oxford.

The work of elinical research units, of external staffs, wholly or partly financed by the Council, and of individual research workers receiving grants, are summarized in the report, and many valuable contributions have been made to medical knowledge.

It is the intention to move the National Institute at Hampstead to Mill Hill, in association with the Farm Laboratories there, but this has been delayed by the war emergency. Some of the ancillary buildings are, however, ready for occupation, and the shell of the main building is nearing completion.

\section{O B I T U A R I E S}

\section{Prof. J. H. Michell, F.R.S.}

$\mathrm{T}$ HE death on February 3 of Prof. J.H. MichelI, at the age of seventy-six, is a severe loss to Australia, and the great value of his work both as mathematician and teacher cannot be easily overestimated. His modesty was such that proper appreciation of his real worth was often confined to the fortunate few who were in close contact with him, either through his undergraduate lectures or some research problem.

After an early education in Melbourne, Michell proceeded to Cambridge, where his performance at the Mathematical Tripos and afterwards led to his early election as a fellow of Trinity College. Here he devoted himself to research in elasticity and hydrodynamics, and a remarkable number of important papers in both subjects resulted. $\mathrm{He}$ was largely responsible for the introduction of stress equations of equilibrium of an elastic solid which did not involve explicit introduction of the displacementequations and provided a formal solution of the equations for an isotropic solid with a plane face under given surface tractions. The important theory of that type of deformation known as dislocation was first developed by Michell and he was also one of the first to make use of inversion in solving problems of plane strain and the bending of plates. His work in elasticity included very valuable discussions of the general theory of bending of beams and plates under various loads, besides the detailed solution of a number of special problems such as the elastic equilibrium of conical bodies, the calculation of strains due to concentrated loads, the deformation of naturally curved rods, etc. On the dynamical side of the subject Michell was responsible for the theory of the vibrations of a helical rod and of a circular ring. Perhaps his most interesting contribution to hydrodynamics is the theory of the 'highest' wave in water, but he also published work on discontinuous fluid motion and on wave resistance to ships.
As a just recognition of this excellent work, Michell was elected a fellow of the Royal Society in 1902. A few years later he was appointed lecturer in mathematics in the University of Melbourne and began a long career of devotion to the teaching of the subject. In 1923 he was appointed professor of mathematics and his influence became still more pronounced. To his honours students, among whom I had the privilege to be numbered, Michell was the very personification of mathematical erudition. An hour's lecture by him was an intellectual treat and a whole course of lectures something to look forwaird to with keen anticipation.

Michell was a great exponent of vector methods and was remarkably facile in their manipulation. $\mathrm{He}$ was undoubtedly one of the few mathematicians of his time who really thought in terms of vectors, and he was at pains to educate his students also to think in this way, which is, after all, the natural one for mathematical physics. His influence in spreading a proper appreciation of vector methods represents alone a very important contribution to applied mathematics.

When Michell retired from his chair in 1928 his valuable services were partly retained as honorary research professor. Despite the heavy calls on his time from his academic duties, Michell kept well abreast of all developments in his special subjects and gave several courses of lectures on modern hydrodynamics after his retirement. In 1937 he also published, with his colleague, Mr. M. H. Belz, a treatise on the elements of analysis which is an excellent illustration of the combination of vigour and clarity which characterized his approach to all mathematical problems.

Prof. Michell's modesty and good nature, combined with his remarkable intellectual qualities and willingness to assist in the smoothing-out of difficulties, however trivial, endeared him to his students, all of whom will remember him with affection and admiration.

H. S. W. MASSEY. 